\title{
Seasonal Stability of a Flexible Algal-Cnidarian Symbiosis in a Highly Variable Temperate Environment
}

\author{
James L. Dimond \\ Shannon Point Marine Center \\ Brian L. Bingham \\ Western Washington University, brian.bingham@wwu.edu \\ Gisèle Muller-Parker \\ Shannon Point Marine Center \\ Kaela Wuesthoff \\ Shannon Point Marine Center \\ Lisbeth Francis \\ Shannon Point Marine Center
}

Follow this and additional works at: https://cedar.wwu.edu/esci_facpubs

Part of the Environmental Sciences Commons

\section{Recommended Citation}

Dimond, James L.; Bingham, Brian L.; Muller-Parker, Gisele; Wuesthoff, Kaela; and Francis, Lisbeth, "Seasonal Stability of a Flexible Algal-Cnidarian Symbiosis in a Highly Variable Temperate Environment" (2011). Environmental Sciences Faculty and Staff Publications. 5 .

https://cedar.wwu.edu/esci_facpubs/5 


\title{
Seasonal stability of a flexible algal-cnidarian symbiosis in a highly variable temperate environment
}

\author{
J. L. Dimond,a,* B. L. Bingham,a,b G. Muller-Parker,a,1 K. Wuesthoff,a and L. Francis ${ }^{\mathrm{a}}$ \\ a Shannon Point Marine Center, Western Washington University, Anacortes, Washington \\ b Department of Environmental Sciences, Western Washington University, Bellingham, Washington
}

\begin{abstract}
We evaluated the seasonal stability of two algal symbiont populations in the temperate intertidal sea anemone Anthopleura elegantissima on San Juan Island, Washington, where the relatively thermally tolerant dinoflagellate Symbiodinium muscatinei coexists with the less thermally tolerant chlorophyte Elliptochloris marina. Random collection of anemones along repeatedly sampled transects over four seasons and three shore heights revealed $S$. muscatinei to be the dominant symbiont, with E. marina mostly limited to anemones in the lower intertidal zone. At the lowest shore height sampled (+0.2 m), the proportion of E. marina was between $40 \%$ and $50 \%$ of the total symbiont population throughout the year. Symbiont distribution patterns persisted despite considerable seasonal variation in aerial exposure, temperature, irradiance, nutrients, and phytoplankton concentration, as well as a high potential for symbiont shuffling, with mixed-symbiont assemblages occurring in $51 \%$ of all anemones sampled. Symbiont density in anemones also changed little despite three- to fourfold-higher division frequencies of both symbionts during July and November. Although the intertidal zonation of these symbionts was stable over an annual period, we predict that their spatial distributions will be responsive to longer-term environmental change, and anticipate that this anemone symbiosis will be a useful and highly tractable barometer for future climate change, with this study serving as a baseline.
\end{abstract}

A diverse array of shallow-water cnidarians, including sea anemones, corals, jellyfish, and hydroids, engage in endosymbioses with phototrophic dinoflagellates (Symbiodinium spp.) that translocate photosynthetic products to their host. Many of these symbioses exhibit plasticity with respect to both the population density and genetic identity of the dinoflagellate partner, allowing them to exploit a wide range of conditions that vary spatially and temporally. In tropical systems, where cnidarian symbioses are particularly well studied, many hosts show depth-related differences in symbiont density and physiology, and also undergo predictable seasonal fluctuations in symbiont density and physiology that are correlated with environmental conditions (Fitt et al. 2000; Warner et al. 2002). In addition, some hosts can associate with multiple genotypes of the diverse genus Symbiodinium, with symbiont genotype varying both over time and over spatial scales ranging from individuals to entire regions (reviewed by van Oppen et al. 2009). Distinct symbiont genotypes often differ physiologically, and correspondence between symbiont physiology and the physical environment is thought to contribute to the adaptive potential of these symbioses (reviewed by van Oppen et al. 2009). In response to environmental change, symbiont populations may undergo change through inputs from exogenous populations (termed "switching"; Baker 2003) or through the differential growth of coexisting populations ("shuffling"; Baker 2003). The extent to which these processes occur in nature under both normal and atypical environmental conditions is not well understood

\footnotetext{
* Corresponding author: jdimond@gmail.com

${ }^{1}$ Present address: Division of Graduate Education, National Science Foundation, Arlington, Virginia
}

and is a subject of much recent study (reviewed by van Oppen et al. 2009).

Cnidarian symbioses in temperate regions also exhibit temporal and spatial variation with respect to symbiont density and genotype, although it has been argued that temperate symbioses are more stable than those in the tropics (Muller-Parker and Davy 2001). Although some temperate symbioses do undergo seasonal fluctuations in symbiont density (Rodolfo-Metalpa et al. 2008), others do not despite substantial variation in environmental conditions at high latitudes (Muller-Parker and Davy 2001; Bergschneider and Muller-Parker 2008). Temperate symbioses are particularly noted for their resilience and stability under prolonged darkness and cold temperatures, conditions that would cause the stress-induced loss of symbionts known as bleaching in tropical cnidarian hosts (Muller-Parker and Davy 2001). The persistence of symbionts under these conditions can to some extent be explained by physiologically hardy temperate symbiont genotypes (Muller-Parker et al. 2007).

Unique among symbiotic cnidarians are the Pacific intertidal sea anemones Anthopleura elegantissima and $A$. xanthogrammica, which host a unicellular chlorophyte, Elliptochloris marina (Letsch et al. 2009), in addition to at least two distinct Symbiodinium genotypes (LaJeunesse and Trench 2000). These abundant and wide-ranging temperate sea anemones span over 30 degrees of latitude from Mexico to Alaska, and A. elegantissima often forms dense clonal aggregations that contribute substantially to rocky intertidal community productivity (Fitt et al. 1982). Latitude is the primary determinant of the symbiont assemblage inhabiting both anemone species, with Symbiodinium californium an exclusively southern symbiont, $S$. muscatinei a wide-ranging southern to north-central symbiont, and $E$. 
marina a central to northern symbiont (Fig. 1; LaJeunesse and Trench 2000; Secord and Augustine 2000; Kitaeff 2007). The biogeography of each of these symbionts corresponds well with their thermal tolerances (Saunders and Muller-Parker 1997; Muller-Parker et al. 2007; McBride et al. 2009). Superimposed on biogeographic clines in these symbioses are substantial vertical gradients in the intertidal zone that help create the relatively broad overlap in symbiont ranges. For example, whereas $E$. marina and $S$. muscatinei co-occur over at least 10 degrees of latitude, E. marina is typically confined to the low intertidal zone because it does not photosynthesize or grow well under the prolonged high-temperature and irradiance conditions characteristic of the upper intertidal zone during summer tidal emersion periods (Saunders and MullerParker 1997; Bergschneider and Muller-Parker 2008). Anemones are typically dominated by a single symbiont, but mixed assemblages of E. marina and $S$. muscatinei are common in individual anemones.

Given the pronounced physiological differences between E. marina and S. muscatinei and their resulting latitudinal and intertidal zonation patterns, the wide range of seasonal variation in the physical environment that occurs at high latitudes might be expected to cause seasonal changes in their relative abundances. Experimental studies have indicated that the growth and abundance of both of these symbionts in hospite respond quickly to changes in light and temperature (Saunders and Muller-Parker 1997), and that anemones can switch symbionts upon transplantation to new environments (Bates 2000; Secord and MullerParker 2005). However, the larger question of whether natural populations of algal symbionts undergo shifts in the relative abundance of $E$. marina and $S$. muscatinei over annual seasons and as a function of shore height has not been fully evaluated. A study by Dingman (1998) found stable proportions of the two symbionts during winter and summer at the upper and lower intertidal distribution limits of $A$. elegantissima, but the coarse spatial and temporal resolution of the study limits strong conclusions about symbiosis stability. Determining the relative abundance of these symbionts over an annual period is essential to understanding these associations within the context of considerable seasonal fluctuations in environmental conditions. In this study, we used a random sampling approach to follow a population of A. elegantissima in Washington State over three shore heights and four seasons. In addition to measuring environmental parameters, anemone size, symbiont densities, and relative abundances, we measured algal photosynthetic pigments and division frequencies to determine if these symbiont characteristics vary seasonally in their host anemones and contribute to observed algal symbiont distribution patterns in the intertidal zone.

\section{Methods}

Description of the study site-The Washington State intertidal zone, along a gradient from the outer coast to the inland waters of the San Juan Archipelago, has been well characterized with respect to physical processes affecting the distribution of intertidal organisms (Dayton 1971;

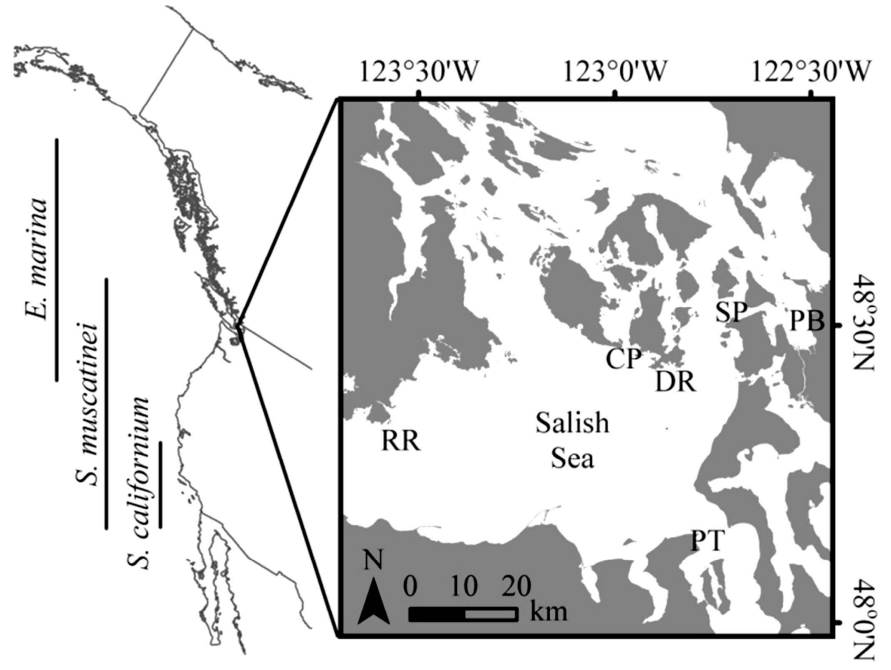

Fig. 1. Biogeography of Anthopleura spp. symbionts along the Pacific coast of North America and an inset map of the study area. The approximate known ranges of the three known symbionts of Anthopleura spp. (Elliptochloris marina, Symbiodinium muscatinei, Symbiodinium californium) were estimated on the basis of Secord and Augustine (2000), LaJeunesse and Trench (2000), and Kitaeff (2007). Inset map of the study area in the Salish Sea includes the locations of the Cattle Point study site (CP), seawater collection sites at Davidson Rock (DR) and Shannon Point Marine Center (SP), irradiance data collection site at Padilla Bay National Estuarine Research Reserve (PB), tidal reference station at Port Townsend (PT), and long-term sea surface temperature data source at Race Rocks Light Station (RR).

Harley and Helmuth 2003). These studies have shown that intertidal organisms in the San Juan Archipelago experience greater potential for heat stress and desiccation during the summer than is the case for communities on the outer coast and in the Strait of Juan de Fuca, largely due to the combined effects of a sunnier climate and low tides that primarily occur midday during the summer. The San Juan Archipelago was therefore selected for this study because its intertidal communities are exposed to a broad seasonal range of environmental conditions during aerial exposure. For our study site, we chose a southeast-facing rocky outcrop at Cattle Point on San Juan Island (Fig. 1) that faces the open waters of the Salish Sea and harbors abundant A. elegantissima.

The oceanography of the region has also been well described. The San Juan Archipelago lies within a fjordtype estuary known as the Salish Sea, including Puget Sound to the south, the Strait of Juan de Fuca to the west, and the Strait of Georgia to the north. In these waters, density-driven estuarine circulation generated largely by the Fraser and Skagit rivers delivers an abundant supply of nutrient-rich oceanic and riverine waters that support high productivity (Stockner et al. 1979; Harrison et al. 1994). Most nutrients are supplied as a result of coastal upwelling of deep, nutrient-rich, high-salinity oceanic water that gradually moves shoreward through the Strait of Juan de Fuca via estuarine circulation and becomes well mixed with surface water during winter periods of relatively low river 
discharge and high winds (Harrison et al. 1994). The Salish Sea is generally characterized by a mid-spring peak phytoplankton bloom initiated by increasing temperature and irradiance, reduced wind speeds, and increased river runoff. Bloom formation may be constrained by a variety of factors, including wind and tidal-driven advection and turbulence, cell sinking and self-shading, and zooplankton grazing, but nutrients are rarely exhausted (Stockner et al. 1979; Harrison et al. 1994).

Environmental data - Sea-surface photosynthetically active radiation (PAR; 400-700 nm) data were obtained from Padilla Bay National Estuarine Research Reserve (Fig. 1; D. Bulthuis, N. Burnett, and H. Bohlmann unpubl. data, Padilla Bay National Estuarine Research Reserve Monitoring Program). Daily integrated PAR was computed by summing data collected at 15-min intervals.

To evaluate the influence of seasonal variation in the timing and duration of aerial exposure on the intertidal thermal regime, daytime periods of continuous aerial exposure at the three shore heights sampled were calculated on the basis of monthly average sunrise and sunset times. Tidal information was obtained using Tides and Currents (Nobeltec) software with Port Townsend, Washington as the reference station (Fig. 1).

Temperatures at the study site were recorded every $5 \mathrm{~min}$ with Hobo WaterTemp Pro data loggers (Onset Computer) encased in white rubber protective boots. Two data loggers were mounted to the rocky substrate with cable ties and stainless-steel eyebolts embedded in marine epoxy: one at $+0.2 \mathrm{~m}$ above mean lower low water (MLLW) and one at $+1.8 \mathrm{~m}$.

Annual variation in seawater characteristics were assessed using data obtained from regular water-quality monitoring at Shannon Point Marine Center (SPMC; Fig. 1). Salinity, nitrate and nitrite, phosphate, and chlorophyll $a$ were measured semiweekly at the seawater intakes at SPMC. An Alpkem RFA300 autoanalyzer was used to measure nitrate and nitrite according to the manufacturer's specifications. Phosphate was assayed using the method of Parsons et al. (1984) with a Spectronic 20D spectrophotometer. For chlorophyll $a$ determination, water samples were filtered onto Whatman GF/F filters under vacuum filtration, followed by extraction for $24 \mathrm{~h}$ at $-20^{\circ} \mathrm{C}$ in $90 \%$ acetone. Centrifuged $\left(1500 \times g\right.$ at $4^{\circ} \mathrm{C}$ for $\left.5 \mathrm{~min}\right)$ extract was read on a Turner 10-AU fluorometer with excitation and emission of $430 \mathrm{~nm}$ and $670 \mathrm{~nm}$, respectively. Chlorophyll $a$ concentration was computed using the method of Lorenzen (1966).

To evaluate whether surface seawater characteristics at SPMC may be used to accurately characterize conditions closer to the study site, we compared SPMC data from 2000-2009 with data collected on the same days at Davidson Rock (Fig. 1). Davidson Rock (along with several other locales) was surveyed approximately three to four times a year using identical methods, and its proximity to Cattle Point makes it a potentially useful proxy. Regression analysis of nutrient and chlorophyll data comparing SPMC and Davidson Rock indicated that seawater from the two sites was similar with respect to nitrate and nitrite $\left(n=25 ; r^{2}=0.92, p<0.001\right)$, phosphate $\left(n=23 ; r^{2}=0.39, p<0.01\right)$, and chlorophyll $a\left(n=21 ; r^{2}\right.$ $=0.87, p<0.001)$ concentrations. However, salinity was not similar between the two sites $\left(n=22 ; r^{2}=0.17, p=\right.$ $0.06)$. We therefore expect that SPMC data represent a reliable proxy for seawater nutrient and chlorophyll concentrations but not for salinity at the Cattle Point study site.

Anemone sampling-At Cattle Point, we established three $25-\mathrm{m}$ permanent horizontal transects at $+0.2 \mathrm{~m}$, $+1.2 \mathrm{~m}$, and $+2.0 \mathrm{~m}$ above MLLW. These shore heights were selected to span the central zone of A. elegantissima distribution; individuals were located above (mostly in isolated tide pools) and below this central zone. Transect locations, marked with colored tags embedded in marine epoxy, were sampled during low tides on 16 July 2008, 11 November 2008, 06 February 2009, and 27 April 2009. For each sampling event, 25 anemones from randomly selected locations along each transect were collected and placed into individually numbered plastic bags for transport back to SPMC within $12 \mathrm{~h}$. At SPMC, the anemones were cleaned of attached debris and gravel and placed into numbered glass dishes in a flow-through seawater table with natural window lighting. All anemones were photographed, weighed, and homogenized with $5-\mu \mathrm{m}$-filtered seawater in a small blender within $3 \mathrm{~d}$ of collection. Samples of fresh anemone homogenate were filtered immediately to collect chlorophylls, and several additional samples were frozen at $-70^{\circ} \mathrm{C}$ for later analysis.

Anemone biomass and symbiont density —Protein biomass is assumed to be the most accurate metric of anemone size because it is not affected by tissue water retention or anemone expansion as wet weight and oral disk diameter are. Nevertheless, it was of interest to determine how accurately the latter commonly used assays of size and weight reflected protein content. Wet weight was determined by gently blotting anemones on paper towels to remove surface water before weighing on a digital balance. Oral disk diameter was measured with Image-J (National Institutes of Health) software using calibrated digital images of anemones photographed while fully expanded in small dishes filled with seawater. The soluble protein content of anemone homogenates was determined by the method of Lowry et al. (1951), with bovine serum albumin as the standard. Two replicate samples from each anemone homogenate were analyzed for protein on a Spectronic 20D spectrophotometer.

Elliptochloris marina and $S$. muscatinei are easily distinguished under light microscopy, since E. marina is green and small $(8-10 \mu \mathrm{m})$ compared with $S$. muscatinei, which is larger $(10-13 \mu \mathrm{m})$ and golden brown. Algal symbionts in homogenates were identified and counted with a hemacytometer under a compound microscope, with four replicate counts of at least $80-100$ cells for samples with dense symbiont populations. For samples with few symbionts, a maximum of 16 hemacytometer chambers was counted. Symbiont numbers were normalized to anemone protein biomass to provide a standardized measure of 
symbiont density in each anemone. In cases where anemones harbored both species of symbiont, the density and proportion of each symbiont were calculated.

Symbiont mitotic index and chlorophyll content-The percentage of dividing symbiont cells in a homogenate sample, mitotic index (MI), was determined by counting 1000 cells at $400 \times$ under a compound microscope and calculating the percentage of cells with a well-defined division furrow. For anemone homogenates with mixed symbiont assemblages, the MI of both algal symbionts was counted if the less abundant one was at least $30 \%$ of the algal population.

Symbiont chlorophyll was collected by vacuum filtration of algae in fresh anemone homogenate onto Whatman GF/C filters. Filters were then wrapped in foil and frozen at $-70^{\circ} \mathrm{C}$ until analysis. Upon analysis, filters were ground with a motorized Teflon tissue grinder using either acetone or methanol as the solvent. Ice-cold $100 \%$ acetone was used for samples dominated ( $>80 \%$ ) by S. muscatinei, and $100 \%$ methanol was used for samples dominated ( $>$ $80 \%$ ) by E. marina. Mixed-symbiont samples were excluded to simplify analysis. Pigments in ground filters were extracted for $24 \mathrm{~h}$ at $-20^{\circ} \mathrm{C}$, centrifuged $(1500 \times g$ at $4^{\circ} \mathrm{C}$ for $5 \mathrm{~min}$ ) to pellet the filter, and analyzed on an Agilent 8453A ultraviolet-visible diode array spectrophotometer. For $100 \%$ acetone samples $(>80 \%$ S. muscatinei), absorbance at 630 and $663 \mathrm{~nm}$ was used to determine chlorophylls $a$ and $c_{2}$ using the equations of Jeffrey and Humphrey (1975). For $100 \%$ methanol samples (> 80\% E. marina), absorbance at 650 and $665 \mathrm{~nm}$ was used to determine chlorophylls $a$ and $b$ with the equations of Holden (1976).

Statistical analyses-Two-way ANOVA was used to analyze the effects of season and shore height on anemone biomass, anemone symbiont complement (relative abundance), symbiont density, symbiont MI, and symbiont chlorophyll content. Data for higher shore heights were limited for E. marina MI and chlorophyll content, so shore height was not evaluated for these data and one-way ANOVA with the effect of season was performed. Levene's test showed significant variance heterogeneity in all data sets. For MI data and S. muscatinei density data, this was resolved with square-root and log transformations, respectively. For all other measurements that could not be corrected with data transformation, we adjusted alpha to 0.025 to reduce the probability of type I error (Keppel and Wickens 2004). When variances were significantly heterogeneous, Dunnett's T3 test was used for post hoc analyses; otherwise, the Tukey honestly significant difference (HSD) test was used. All analyses were performed using Predictive Analytics SoftWare Statistics version 18.

\section{Results}

Environmental characteristics-The intertidal environment at the study site varies seasonally and by shore height, with seasonal fluctuations of both solar irradiance and the timing of low tides coinciding to influence the intertidal
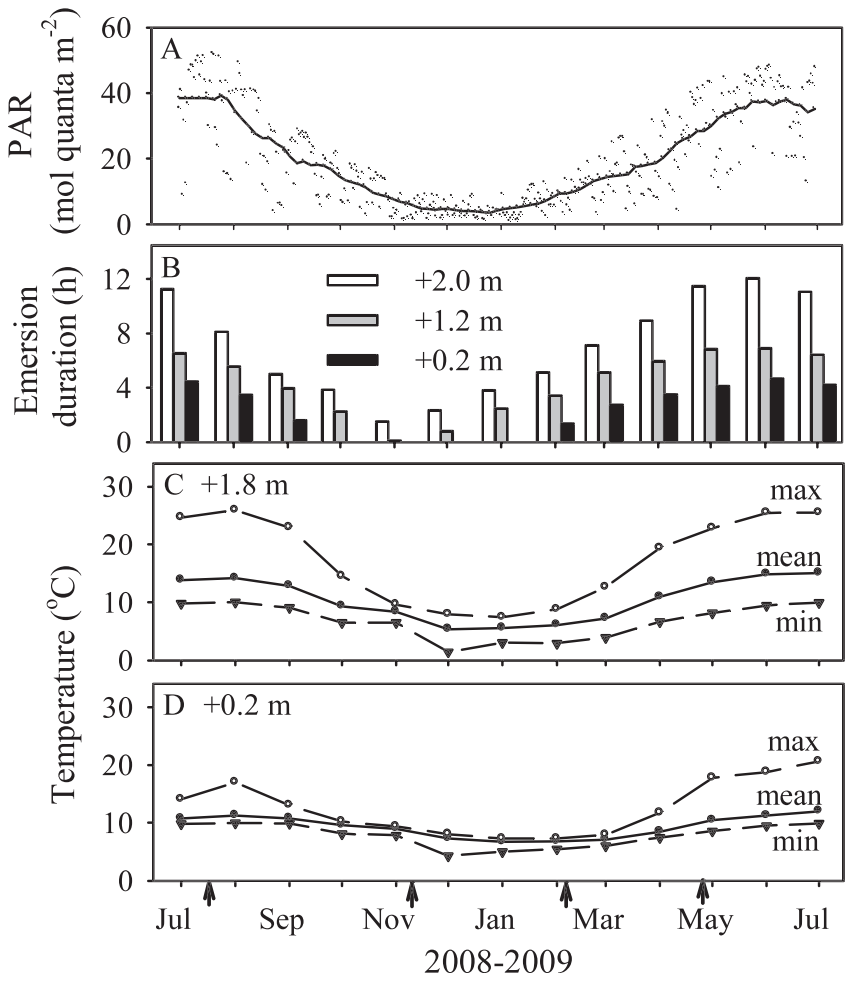

Fig. 2. Sea surface irradiance, daytime tidal emersion, and temperature during the study period. (A) Daily integrated PAR with a running average (solid line). (B) Mean continuous duration of daytime tidal emersion (aerial exposure between sunrise and sunset) by month and shore height. (C, D) Monthly maximum (max), mean, and minimum ( $\min )$ temperatures recorded in situ at (C) $+1.8 \mathrm{~m}$ and (D) $+0.2 \mathrm{~m}$ above MLLW. Arrows on $x$-axis indicate the dates of Anthopleura elegantissima field sampling.

temperature environment, especially for high shore locations (Fig. 2). The effect of increased irradiance on temperature from late spring to early autumn is accentuated in the intertidal zone by an increase in the duration of daytime emergence during this period (Fig. 2A,B). During winter, when low tides occur predominantly at night, exposure to cold air results in cooler temperatures at high shore locations. The high intertidal zone therefore experiences a considerably wider range of temperatures than the low intertidal zone because of increased emersion periods year-round (Fig. 2C,D).

During the 2008-2009 sampling period, surface seawater was characterized by increased nitrate and nitrite concentrations during winter months, and reductions in chlorophyll $a$ concentrations from mid-autumn to midwinter (Fig. 3). Phosphate concentrations did not show any clear seasonal trend. Compared with the $10-\mathrm{yr}$ average (20002009), 2008-2009 was a fairly typical year, except that phosphate did not increase during winter. Given that SPMC salinity was a poor predictor of Davidson Rock salinity, it is not appropriate to make generalizations about salinity at the study site; however, salinity data are presented (Fig. 3A) to show that salinity in the area does not fluctuate widely. Ammonia concentrations in Puget Sound range from 0 to $4 \mu \mathrm{mol} \mathrm{L} \mathrm{L}^{-1}$ but do not exhibit 


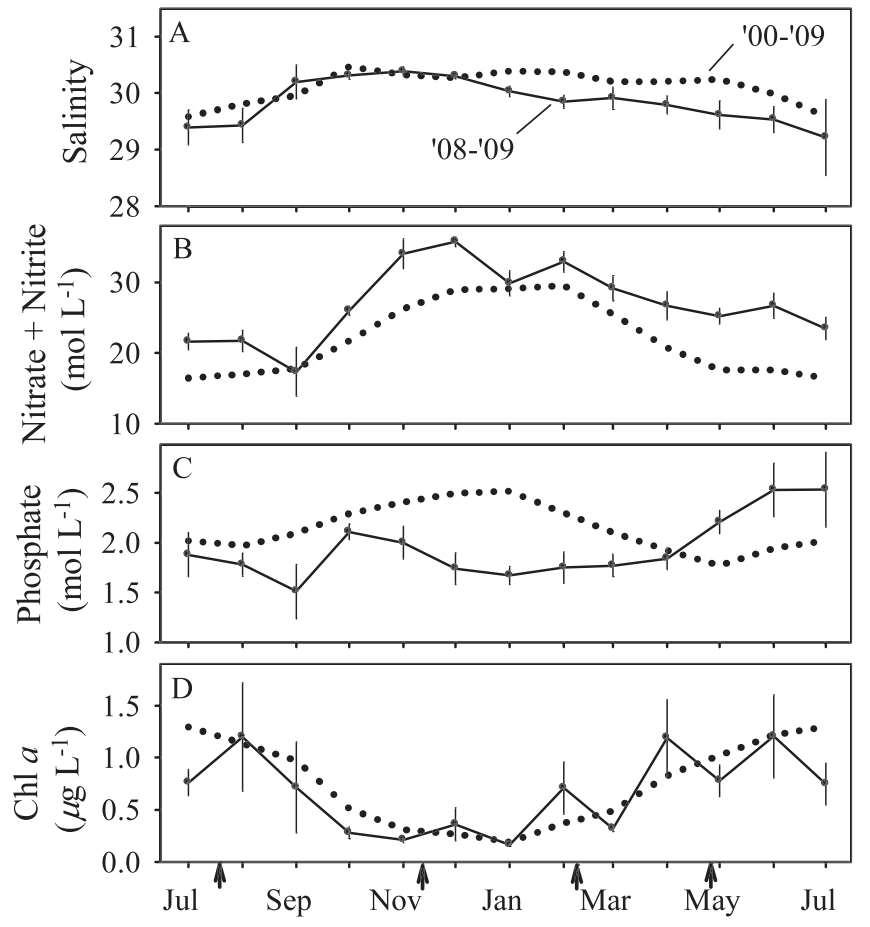

Fig. 3. Physical and biological characteristics of surface seawater. Monthly averages ( \pm SE) for the 2008-2009 study period ( $n=5-9$ samples per month), together with monthly averages for the decade: (A) salinity, (B) nitrate and nitrite, (C) phosphate, and (D) chlorophyll $a(\mathrm{Chl} a)$ concentration. Arrows on $x$-axis indicate the dates of $A$. elegantissima field sampling.

seasonal trends as nitrate and phosphate do (Thom and Albright 1990).

Anemone biomass and symbiosis-All metrics of anemone size (Table 1) indicated significant seasonal variation (protein biomass, $F_{3,286}=12.9, p<0.001$; wet weight, $F_{3,287}=3.52, p=0.02$; oral disk diameter, $F_{3,287}=9.60, p$ $<0.001)$. There were no significant shore height differences in any measure (protein biomass, $F_{2,286}=2.36, p=0.09$; wet weight, $F_{2,287}=1.97, p=0.14$; oral disk diameter, $\left.F_{2,287}=1.35, p=0.26\right)$ and no significant interaction effects (protein biomass, $F_{6,286}=0.84, p=0.54$; wet weight, $F_{6,287}=0.96, p=0.45$; oral disk diameter, $F_{6,287}=$ $1.24, p=0.29)$. Wet weight was a better predictor of protein biomass than was oral disk diameter (Table 1). However, although protein biomass was significantly

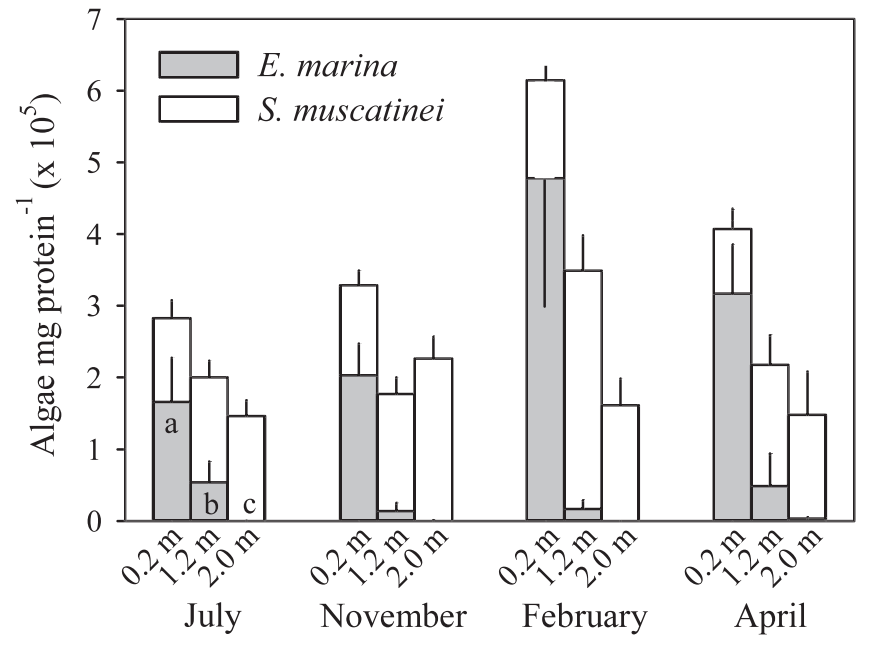

2008-2009

Fig. 4. Densities (mean $\pm \mathrm{SE} ; n=24-25$ ) of $S$. muscatinei and E. marina in Cattle Point A. elegantissima. Samples were collected on 16 July 2008, 11 November 2008, 06 February 2009, and 27 April 2009. Significant differences were detected only for the density of E. marina according to shore height; shore heights with different letters within the first set of bars were significantly different.

higher in November than in all other months, wet weight was not significantly different among July, November, and February.

Overall, S. muscatinei was the more common and widely distributed symbiont throughout the intertidal zone (Fig. 4). E. marina was relatively abundant at $+0.2 \mathrm{~m}$, less common at $+1.2 \mathrm{~m}$, and extremely rare at $+2.0 \mathrm{~m}$, and this was reflected by significant shore height differences in $E$. marina densities in anemones $\left(F_{2,287}=25.5, p<0.001\right)$. For $S$. muscatinei density within anemones, there was no significant effect of shore height $\left(F_{2,287}=2.40, p=0.09\right)$, and neither symbiont showed significant seasonal differences ( $E$. marina, $F_{3,287}=0.87, p=0.46 ; S$. muscatinei, $\left.F_{3,287}=0.99, p=0.39\right)$ or interaction effects $(E$. marina, $F_{6,287}=1.05, p=0.39 ; S$. muscatinei, $F_{6,287}=1.03, p=$ 0.41 ). There was a trend toward increased $E$. marina densities during February and April, but this trend was not significant. The large variability in E. marina density was caused by high densities of symbionts in a few individuals harboring $>95 \%$ E. marina; four anemones in February had E. marina densities between 1 and $3 \times 10^{6} \mathrm{mg}$ $\operatorname{protein}^{-1}$.

Table 1. Summary and comparison of Anthopleura elegantissima biomass measurements (mean \pm SD). The results of pairwise comparisons (Dunnett's T3 for protein biomass and oral disk diameter; Tukey HSD for log-transformed wet weight) of anemones sampled in different months are shown, with significant differences indicated by different letters. Regression statistics comparing wet weight and oral disk diameter with protein biomass are shown below the table.

\begin{tabular}{lcccc}
\hline \hline Month & Protein biomass $(\mathrm{mg})$ & Wet weight $(\mathrm{g})^{*}$ & Oral disk diameter $(\mathrm{cm}) \dagger$ & $n$ \\
\hline July & $118.9(130.0) \mathrm{b}$ & $0.89(2.80) \mathrm{ab}$ & $1.5(0.6) \mathrm{a}$ & 74 \\
November & $197.3(200.0) \mathrm{a}$ & $1.04(2.77) \mathrm{a}$ & $1.4(0.7) \mathrm{a}$ & 74 \\
February & $74.4(51.6) \mathrm{c}$ & $0.71(2.06) \mathrm{ab}$ & $1.2(0.3) \mathrm{b}$ & 75 \\
April & $91.2(99.9) \mathrm{bc}$ & $0.68(2.57) \mathrm{b}$ & $1.8(0.8) \mathrm{a}$ & 75 \\
\hline
\end{tabular}

\footnotetext{
* Protein $=67.31 e^{(0.314 \times \text { wet weight })}, r^{2}=0.80$.
}

$\dagger$ Protein $=45.55 e^{(0.650 \times \text { diameter })}, r^{2}=0.33$ 


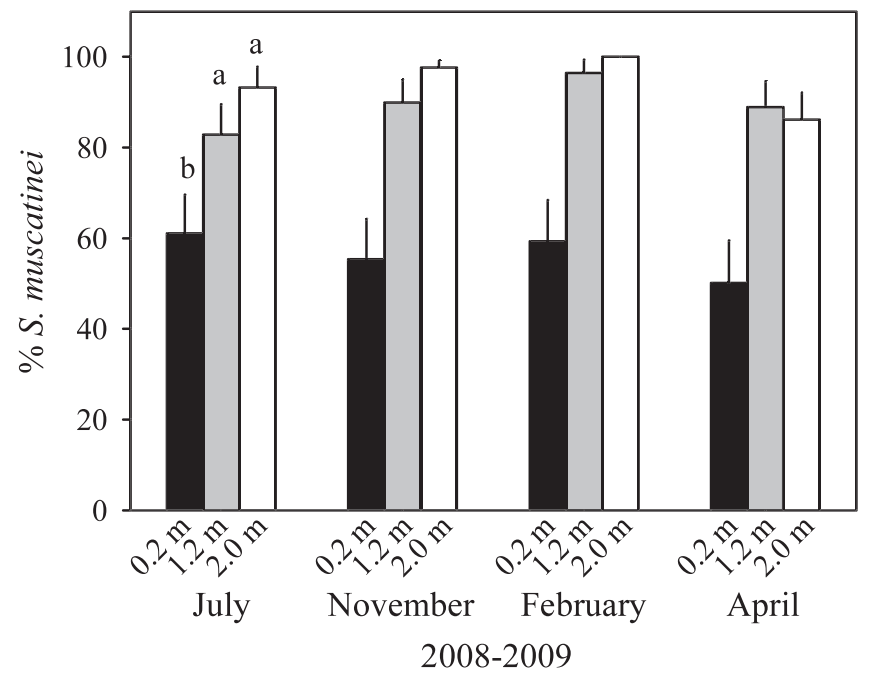

Fig. 5. Relative abundance of $S$. muscatinei and E. marina per anemone at Cattle Point, expressed as the percentage of symbionts that were $S$. muscatinei (mean \pm SE; $n=24-25$ ). Samples were collected on 16 July 2008, 11 November 2008, 06 February 2009, and 27 April 2009. Significant differences were detected between shore heights but not between sampling dates; shore heights with different letters above the first set of bars were significantly different for all months.

The average percent symbiont complement per anemone was significantly different between shore heights $\left(F_{2,287}=\right.$ $43.5, p<0.001)$, with percentages of $S$. muscatinei lower (and E. marina higher) at $+0.2 \mathrm{~m}$ than at +1.2 or $+2.0 \mathrm{~m}$ (Fig. 5). Anemones at $+0.2 \mathrm{~m}$ hosted on average between $50 \%$ and $60 \%$ S. muscatinei ( $=40 \%$ to $50 \%$ E. marina). There was a trend of increasing $S$. muscatinei and decreasing E. marina percentage with increasing shore height. We found no significant seasonal shift in symbiont complement at the population level $\left(F_{3,287}=1.00, p=\right.$ 0.39 ), and the interaction term was also not significant $\left(F_{6,287}=0.56, p=0.76\right)$.

Fifty-one percent of all anemones sampled harbored mixed-symbiont assemblages, with a background symbiont detection limit of approximately $0.1 \%$ of the total symbiont population. Mixed-symbiont assemblages decreased in frequency with increasing shore height; $70 \%$ were mixed at $+0.2 \mathrm{~m}, 44 \%$ at $+1.2 \mathrm{~m}$, and $38 \%$ at $+2.0 \mathrm{~m}$.

Mitotic index-Although the MI of E. marina was up to 10 times that of $S$. muscatinei, the seasonal trends in MI were remarkably similar (Fig. 6A,B). Both algal symbionts showed similar and significant seasonal differences in MI (S. muscatinei, $F_{3,188}=65.9, p<0.001 ; E$. marina, $F_{3,36}=$ 27.2, $p<0.001)$, with higher percentages of cells undergoing division in July and November than in February and April. For S. muscatinei, there was a marginally significant effect of shore height, with a trend of increasing MI with decreasing shore height $\left(F_{2,188}=\right.$ $3.13, p=0.05)$. The interaction term was not significant $\left(F_{6,188}=0.61, p=0.72\right)$. Because $E$. marina was rare in anemones at the two higher shore heights, MI was only determined for a limited number of anemones at $+1.2 \mathrm{~m}$ and for no anemones at $+2.0 \mathrm{~m}$, and the analysis was

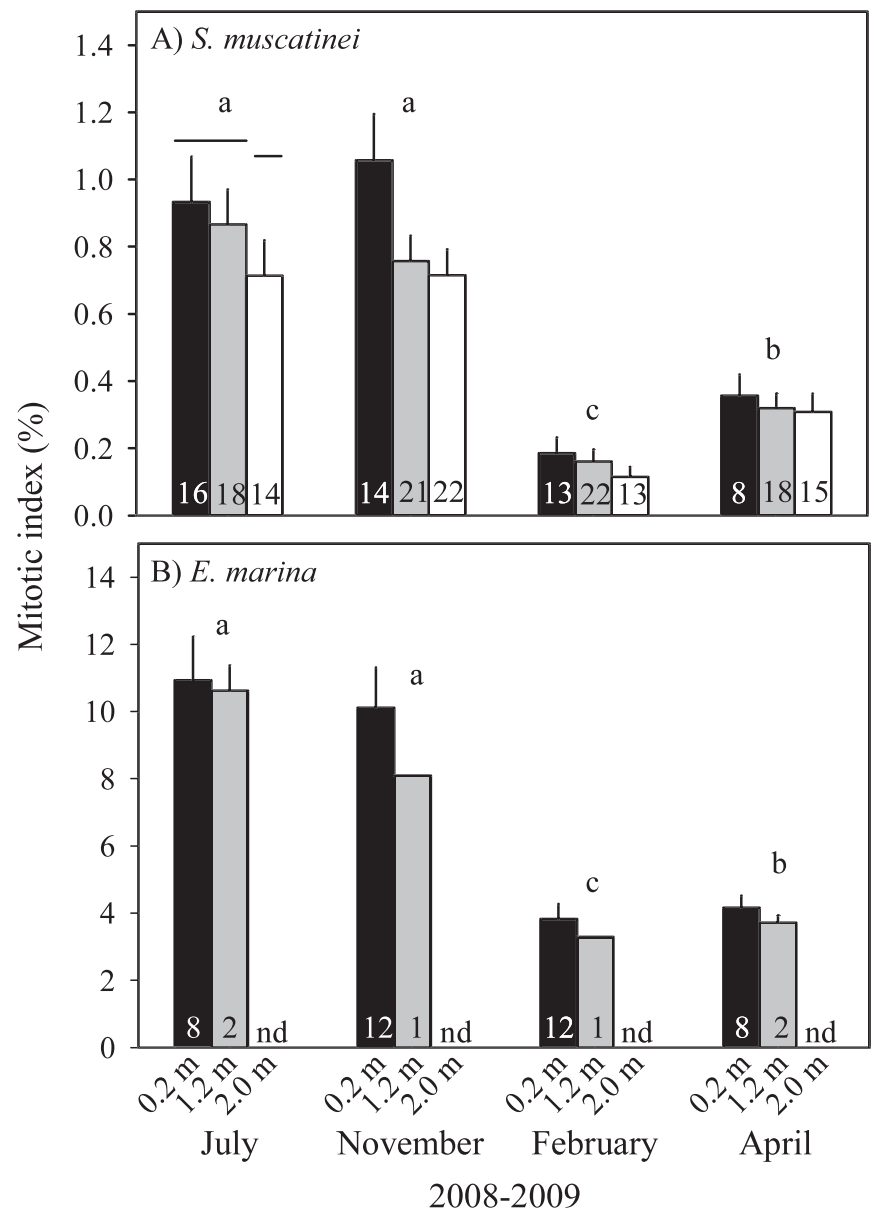

Fig. 6. Mitotic index of (A) S. muscatinei and (B) E. marina at Cattle Point (mean \pm SE; $n$ is indicated within each bar; nd $=$ no data). Samples were collected on 16 July 2008, 11 November 2008, 06 February 2009, and 27 April 2009. Significant differences between sampling dates were detected for both symbionts; sampling dates with different lowercase letters above the bars were significantly different. Significant differences between different shore heights across all months for $S$. muscatinei MI are indicated by horizontal lines above the first set of bars.

limited to a one-way ANOVA on season using only data from $+0.2 \mathrm{~m}$.

Chlorophyll-For S. muscatinei, a significant effect of season was found for all chlorophyll parameters (Fig. 7AC), including chlorophyll $a\left(F_{3,192}=22.5, p<0.001\right)$, chlorophyll $c_{2}\left(F_{3,191}=11.7, p=0.001\right)$, and chlorophyll $a: c_{2}$ ratio $\left(F_{3,190}=5.30, p<0.01\right)$. For chlorophylls $a$ and $c_{2}$, July values were higher than those for all other months, whereas for chlorophyll $a: c_{2}$ ratio, February values were highest. Additionally, significant shore height effects were found for chlorophyll $a: c_{2}$ ratio $\left(F_{2,190}=9.28, p=0.02\right)$, with higher values at $+1.2 \mathrm{~m}$ than at $+2.0 \mathrm{~m}$ (these effects are not shown in the figure because of the nonintuitive nature of the Dunnett's T3 post hoc results). There were no significant effects of shore height on chlorophyll $a$ or $c_{2}$ (chlorophyll $a, F_{2,192}=3.46, p=0.03, \alpha=0.025$; chlorophyll $\left.c_{2}, F_{2,191}=0.62, p=0.54\right)$, and the interaction terms were not significant for any chlorophyll parameters 


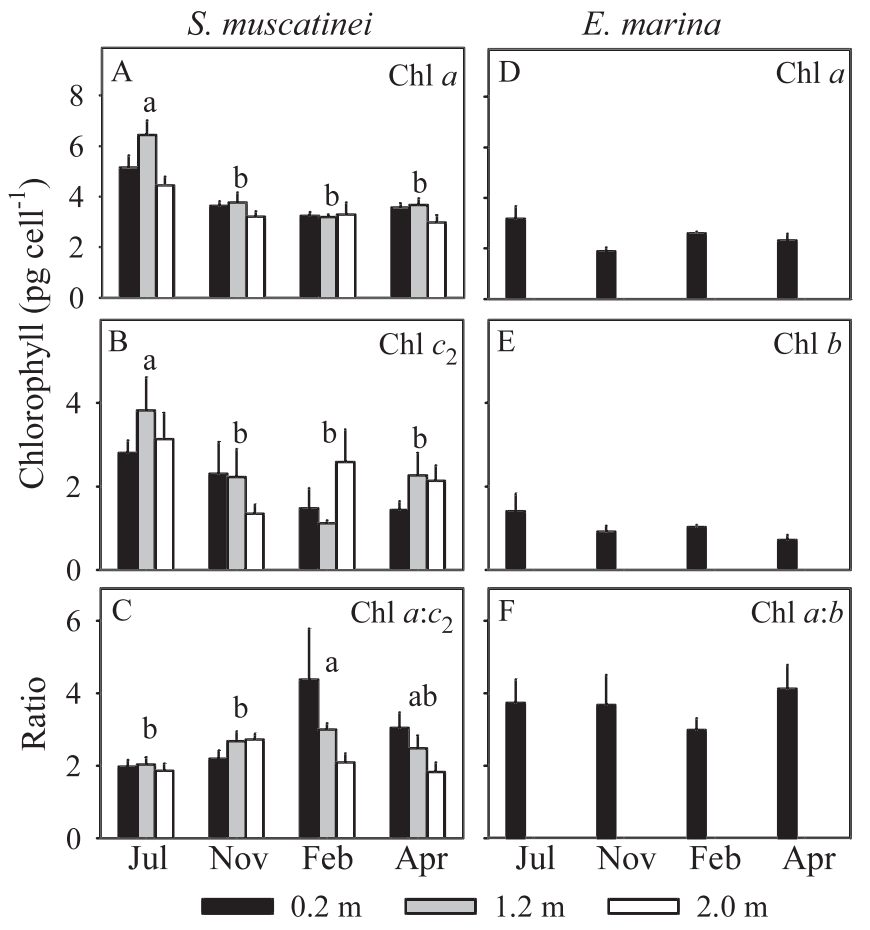

Fig. 7. Cell-specific chlorophyll concentrations and ratios (mean $\pm \mathrm{SE})$ for $(\mathrm{A}-\mathrm{C}) S$. muscatinei $(n=11-21)$ and $(\mathrm{D}-\mathrm{F}) E$. marina $(n=8-12)$. Data for E. marina at $+1.2 \mathrm{~m}$ and $2.0 \mathrm{~m}$ were insufficient for analysis. Significant differences between sampling dates were detected for all measurements except $E$. marina chlorophyll $b$ concentration and chlorophyll $a: b$ ratio. Sampling dates with different lowercase letters above the bars were significantly different (see text for exceptions). Significant differences between different shore heights across all months were also found for $S$. muscatinei chlorophyll $a: c_{2}$ ratios.

(chlorophyll $a, F_{6,192}=1.11, p=0.36$; chlorophyll $c_{2}, F_{6,191}$ $=1.07, p=0.38$; chlorophyll $a: c_{2}, F_{6,190}=2.38, p=0.03$, $\alpha=0.025$.

As with MI data, the limited occurrence of E. marina in the two higher transects meant that no chlorophyll data were available for the +2.0 - $\mathrm{m}$ transect and very few data for the $+1.2-\mathrm{m}$ transect, so one-way ANOVA on season was used. Chlorophyll $a$ content showed a marginally significant effect of season (Fig. 7D; $F_{3,34}=3.56, p=0.02, \alpha=$ 0.025 ), with values in February significantly higher than those in November (these differences are not shown in the figure because of the nonintuitive nature of the Dunnett's $\mathrm{T} 3$ post hoc results). There were no significant differences for chlorophyll $b$ (Fig. 7E, $F_{3,34}=2.05, p=0.12$ ) or chlorophyll $a: b$ ratio (Fig. $7 \mathrm{~F}, F_{3,34}=2.24, p=0.10$ ).

\section{Discussion}

Despite considerable annual variation in environmental factors, the intertidal population of A. elegantissima at Cattle Point hosted largely stable proportions of $E$. marina and $S$. muscatinei over four seasons. E. marina was more abundant at lower shore levels as other studies have shown (Bates 2000; Secord and Augustine 2000), but symbiont distribution did not change seasonally. Our results concur with those of Dingman (1998), who found stable relative abundances of $E$. marina and $S$. muscatinei in $A$. elegantissima during summer and winter 1996 at a cobble beach on Fidalgo Island, Washington. With increased spatial and temporal resolution, our study indicates that stability prevails throughout the year, and that the vertical gradient of symbiont relative abundance does not appear to change seasonally. These results are surprising given that Anthopleura spp. symbiont assemblages can respond and shift within days to months of experimental changes in environmental conditions (Saunders and Muller-Parker 1997; Bates 2000; Secord and Muller-Parker 2005). Furthermore, we detected mixed-symbiont assemblages in half of the anemones sampled, indicating a high potential for symbiont shuffling. Although the seasonal environmental fluctuations these symbioses experience are large, their pace and intensity are apparently insufficient to cause symbiont shifts.

Among well-studied tropical corals, multisymbiont associations can be either seasonally dynamic (Chen et al. 2005) or largely stable over seasonal and multiyear timescales (Goulet 2006; Thornhill et al. 2006). In a longterm survey of Symbiodinium diversity in several Caribbean scleractinian corals, Thornhill et al. (2006) found that changes in symbiont assemblages were more likely to occur at higher latitudes, shallower depths, and after environmental perturbations, suggesting that greater variation in the physical environment causes symbiont shifts. There was a tendency, however, for symbiont assemblages to revert back to the more typical symbiont in absence of further environmental anomalies (Thornhill et al. 2006). The Washington intertidal environment we studied is a highly dynamic physical regime with respect to frequent and extreme swings in temperature during aerial exposure, as well as annual variation in temperature, irradiance, nutrient concentrations, and food availability. Yet, at the population level, A. elegantissima symbioses varied little over the course of a year. In the low intertidal zone, however, the temperature regime is largely driven by sea surface temperatures that typically vary less than $5^{\circ} \mathrm{C}$ annually, and this is predominantly where we found relatively high abundances of E. marina. The persistence of $S$. muscatinei-dominated associations in the upper intertidal zone is likely attributable to the summer high temperatures that exclude E. marina from inhabiting anemones at higher shore levels (Saunders and MullerParker 1997; Bates 2000). The high prevalence of $S$. muscatinei relative to E. marina is consistent with the conclusions of other studies identifying the San Juan Archipelago as a region with particularly high potential for intertidal thermal stress; the combination of a relatively sunny microclimate, low wave splash due to protection from oceanic swells, and a preponderance of midday low tides during the summer contribute to this effect (Dayton 1971; Harley and Helmuth 2003).

Although distinct zonation of the two symbionts may largely reflect their individual physiological tolerances, both the symbionts and their host contribute to the combined physiology of the holobiont, and can equally influence the capacity for acclimatization and adaptation. 
For Anthopleura spp. symbioses, the role of the host is perhaps best illustrated by differential patterns of symbiont latitudinal and intertidal zonation according to host species. E. marina occurs much higher in the intertidal zone and approximately $6^{\circ}$ farther south in A. xanthogrammica than in A. elegantissima (Bates 2000; Secord and Augustine 2000). These contrasting distribution patterns do not appear to be related to differences in habitat or the relative size of the two anemone species (Bates et al. 2010), and suggest that symbiont physiology cannot entirely account for symbiont zonation and biogeography. Nevertheless, the physiological hardiness of high-latitude symbionts is clear (Muller-Parker et al. 2007). For example, the limited southern range of $S$. californium relative to $S$. muscatinei is likely due to the broader thermal tolerance of the latter (Muller-Parker et al. 2007; McBride et al. 2009). This indicates that although the host plays an important role in symbiont distribution patterns, the persistence of symbioses at high latitudes is ultimately dependent on symbionts that are well adapted to the extrinsic environment.

Intertidal symbiont distribution patterns were stable despite a nonsignificant trend toward increased densities of E. marina during February and April. These increases in symbiont density occurred primarily in a few anemones harboring $>95 \%$ E. marina, which explains why symbiont shifts at the anemone population level did not occur. The reason for high $E$. marina densities in some anemones during February and April is unknown, but could be the result of reductions in anemone protein biomass without concomitant reductions in symbiont numbers (i.e., anemone shrinkage). Bergschneider and Muller-Parker (2008) also observed a nonsignificant increase in E. marina densities during early winter. During winter and spring, photosynthetic rates of the two symbionts are approximately equivalent, as opposed to summer when photosynthetic rates are enhanced in $S$. muscatinei relative to $E$. marina (Verde and McCloskey 2007; Bergschneider and Muller-Parker 2008). Coupled with the typically higher densities of E. marina, relatively high photosynthetic rates of these symbionts during winter and spring could create positive feedback effects that promote their proliferation inside the host. Engebretson and Muller-Parker (1999) found that at $13^{\circ} \mathrm{C}$ and moderate irradiance, anemone biomass-specific ${ }^{14} \mathrm{C}$ translocation was higher in anemones hosting E. marina than in those hosting $S$. muscatinei because of higher densities of E. marina. However, these findings contrast with some carbon budget (Verde and McCloskey 2007) and stable isotopic assessments (Bergschneider and Muller-Parker 2008) of symbiont contributions, which point to $S$. muscatinei as the more beneficial symbiont to Washington anemones over the long term.

The MI of both symbionts was three to four times higher during July and November than during February and April, but these months were not characterized by increased symbiont densities. The lack of correspondence between symbiont division and density could be accounted for by the regulation of symbiont densities by postmitotic processes such as expulsion (McCloskey et al. 1996), or seasonal synchrony in patterns of symbiont and host growth (Fitt 2000). Symbiont expulsion rates in $A$. elegantissima are highly responsive to light regime, apparently enabling anemones to maintain constant symbiont densities despite increased MI (McCloskey et al. 1996). There is also evidence to support the hypothesis of coupled host and symbiont growth, as A. elegantissima protein biomass trends approximate those of symbiont MI, with higher values during July and November. The similarity of the seasonal MI trends of the two symbiont species may also account for the lack of temporal changes in their relative abundance, despite the much higher MI of $E$. marina. The higher MI of E. marina is consistent with the findings of several other studies (McCloskey et al. 1996; Verde and McCloskey 2007; Bergschneider and MullerParker 2008).

Symbiont chlorophyll parameters varied over time, particularly among S. muscatinei. However, neither symbiont exhibited patterns indicative of typical photoacclimative responses to reduced wintertime light availability. Chlorophyll $a$ content of both symbionts was highest in July, when light is most available. July is also characterized by extreme high temperatures in the upper intertidal zone, yet $S$. muscatinei at $+2.0 \mathrm{~m}$ showed no evidence of chlorophyll bleaching. Bergschneider and Muller-Parker (2008) also found high chlorophyll $a$ content in $S$. muscatinei during summer and autumn and lower content during the winter. In contrast to our data for E. marina, both Verde and McCloskey (2007) and Bergschneider and Muller-Parker (2008) found increases in chlorophyll during winter, suggestive of photoadaptation. Several hypotheses could explain the absence of typical photoadaptive responses in our data, such as increases in water-column light penetration during winter due to reduced phytoplankton concentrations (see Fig. 3), or metabolic suppression during winter, as suggested by MI trends. The discrepancy between our data and those of previous studies could reflect differences in anemone size, or microhabitat effects that could result in substantial differences in the light and temperature environment.

Temporal scale is an important consideration when evaluating the stability of these A. elegantissima symbioses. Although we did not observe any seasonal changes in symbiont relative abundance, longer-term changes in climate may elicit shifts in symbiont prevalence. Indeed, the biogeography of these symbioses (LaJeunesse and Trench 2000; Secord and Augustine 2000), as well as field and experimental evidence (Muscatine 1971; Saunders and Muller-Parker 1997; Bates 2000), indicate that they are responsive to environmental change. In the laboratory, populations of E. marina in A. elegantissima exhibit reductions in $\mathrm{MI}$ and density within a few days of sustained high temperature $\left(20^{\circ} \mathrm{C}\right.$; Saunders and Muller-Parker 1997). In summer field experiments, Bates (2000) showed that transplantation of $A$. xanthogrammica with $E$. marina from lower to upper intertidal pools induced full shifts to $S$. muscatinei within 2 to 4 months, whereas anemones with $S$. muscatinei moved from high to low shore pools did not switch symbionts. These studies illustrate that anemones are clearly able to undergo symbiont shifts within a single generation (or clone), and suggest that the sensitivity of $E$. 


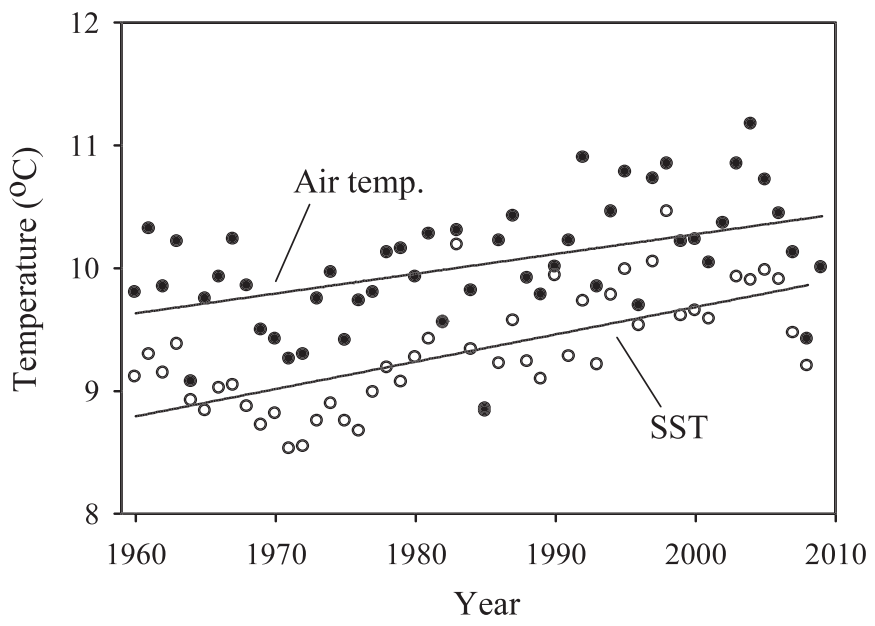

Fig. 8. Annual mean air temperatures (Air temp.; solid symbols) and sea surface temperatures (SST; open symbols) in the Salish Sea region from 1960 to 2009. Air temperatures are for the San Juan Archipelago region (Washington region 2) from the National Climatic Data Center (http://www7.ncdc.noaa.gov/ $\mathrm{CDO} / \mathrm{cdo}$ ). Sea surface temperature records were obtained from Race Rocks Light Station, British Columbia (see Fig. 1; http:// www.pac.dfo-mpo.gc.ca/science/oceans/data-donnees/lighthousesphares/index-eng.htm). Linear regression trend lines are shown.

marina to high temperature makes it a potentially responsive indicator of climate change. This is further supported by the observations of Muscatine (1971), who reported that E. marina was the more prevalent symbiont over 4 decades ago at the same Cattle Point study site we monitored. Specific details of Muscatine's (1971) sampling effort are unknown; he wrote only that A. elegantissima "from Cattle Point harbored mixed populations of zooxanthellae and zoochlorellae with the green algae predominating." Given recent regional warming trends (Fig. 8) and the poleward range shifts of intertidal species observed worldwide (Helmuth et al. 2006), a reduction in $E$. marina abundance over the past $40 \mathrm{yr}$ would not be surprising. Assuming regional warming trends continue, we predict that E. marina abundance will decline at our site over decadal timescales. We propose that long-term changes in this unique dual symbiosis will be a useful climate barometer for the northeastern Pacific coast, and this study will serve as a baseline for future monitoring.

\section{Acknowledgments}

For assistance with field and laboratory work, we thank B. Carpenter, K. Drovdahl, A. Fletcher, I. Freytes, A. Gutierrez, M. Levine, M. Ponce-McDermott, and S. Russell. H.-Y. Lee performed seawater analyses and maintains the SPMC Water Quality Database. The manuscript was improved by the suggestions of two anonymous reviewers.

This study was supported by National Science Foundation grant Integrative Organismal Systems-0822179, with additional contributions from Oceanography-0741372 and Oceanography0551898. Specimens were collected under Washington State Scientific Collection Permit 08-078 and with permission from University of Washington, Friday Harbor Laboratories. This work took place while one of us (G.M.-P.) served in a position at the National Science Foundation. Any opinions, findings, and conclusions or recommendations expressed in this material are those of the authors and do not necessarily reflect the view of the National Science Foundation.

\section{References}

BAKer, A. C. 2003. Flexibility and specificity in coral-algal symbiosis: Diversity, ecology, and biogeography of Symbiodinium. Ann. Rev. Ecol. Syst. 34: 661-689, doi:10.1146/ annurev.ecolsys.34.011802.132417

BAtes, A. 2000. The intertidal distribution of two algal symbionts hosted by Anthopleura xanthogrammica (Brandt 1835). J. Exp. Mar. Biol. Ecol. 249: 249-262, doi:10.1016/S0022-0981 (00)00203-3

Bates, A. E., L. McLean, P. Laing, L. A. Raeburn, and C. Hare. 2010. Distribution patterns of zoochlorellae and zooxanthellae hosted by two Pacific northeast anemones, Anthopleura elegantissima and A. xanthogrammica. Biol. Bull. 218: 237-247.

Bergschneider, H., and G. Muller-Parker. 2008. Nutritional role of two algal symbionts in the temperate sea anemone Anthopleura elegantissima Brandt. Biol. Bull. 215: 73-88, doi: $10.2307 / 25470685$

Chen, C. A., J.-T. WAng, L.-S. FAnG, And Y.-W. YAng. 2005. Fluctuating algal symbiont communities in Acropora palifera (Scleractinia: Acroporidae) from Taiwan. Mar. Ecol. Prog. Ser. 295: 113-121, doi:10.3354/meps 295113

Dayton, P. K. 1971. Competition, disturbance, and community organization: The provision and subsequent utilization of space in a rocky intertidal community. Ecol. Monogr. 41: 351-389, doi:10.2307/1948498

Dingman, H. C. 1998. Environmental influence on algal symbiont populations in the sea anemone Anthopleura elegantissima. M.S. thesis. Western Washington University.

Engebretson, H. P., and G. Muller-Parker. 1999. Translocation of photosynthetic carbon from two algal symbionts to the sea anemone Anthopleura elegantissima. Biol. Bull. 197: 72-81, doi:10.2307/1542998

FitT, W. K. 2000. Cellular growth of host and symbiont in a cnidarian-zooxanthellar symbiosis. Biol. Bull. 198: 110-120, doi: $10.2307 / 1542809$

, F. K. McFarland, M. E. Warner, and G. C. Chilcoat. 2000. Seasonal patterns of tissue biomass and densities of symbiotic dinoflagellates in reef-building corals and relation to coral bleaching. Limnol. Oceanogr. 45: 677-685, doi:10.4319/1o.2000.45.3.0677

-, R. L. Pardy, and M. M. Littler. 1982. Photosynthesis, respiration, and contribution to community productivity of the symbiotic sea anemone Anthopleura elegantissima (Brandt, 1835). J. Exp. Mar. Biol. Ecol. 61: 213-232, doi:10.1016/ 0022-0981(82)90070-3

Goulet, T. L. 2006. Most corals may not change their symbionts. Mar. Ecol. Prog. Ser. 321: 1-7, doi:10.3354/meps321001

Harley, C. D. G., and B. S. T. Helmuth. 2003. Local- and regional-scale effects of wave exposure, thermal stress, and absolute vs. effective shore level on patterns of intertidal zonation. Limnol. Oceanogr. 48: 1498-1508, doi:10.4319/ lo.2003.48.4.1498

Harrison, P. J., D. L. Mackas, B. W. Frost, R. W. MacDonald, AND E. A. CRecelius. 1994. An assessment of nutrients, plankton, and some pollutants in the water column of Juan de Fuca Strait, Strait of Georgia and Puget Sound, and their transboundary transport, p. 138-174. In R. C. H. Wilson, R. J. Beamish, F. Aitkens, and J. Bell [eds.], Review of the marine environment and biota of Strait of Georgia, Puget Sound, and Juan de Fuca Strait. Proceedings of the British 
Columbia/Washington Symposium on the Marine Environment. Canadian Technical Report of Fisheries and Aquatic Sciences Number 1948.

Helmuth, B., N. Mieszkowska, P. Moore, and S. J. Hawkins. 2006. Living on the edge of two changing worlds: Forecasting the responses of rocky intertidal ecosystems to climate change. Annu. Rev. Ecol. Evol. Syst. 37: 373-404, doi:10.1146/annurev.ecolsys.37.091305.110149

Holden, M. 1976. Chlorophylls, p. 1-37. In T. W. Goodwin [ed.], Chemistry and biochemistry of plant pigments. Academic.

Jefrrey, S. W., AND G. F. Humphrey. 1975. New spectrophotometric equations for determining chlorophylls $a, b, c$, and $c 2$ in higher plants, algae, and natural phytoplankton. Biochem. Physiol. Pflanz. 167: 191-194.

Keppel, G., And T. D. Wickens. 2004. Design and analysis. A researcher's handbook. Pearson Prentice Hall.

KitAefF, P. R. N. 2007. Latitudinal differences in the distribution of two algal symbionts within the intertidal sea anemone, Anthopleura xanthogrammica. M.S. thesis. Western Washington University.

LaJeunesse, T. C., and R. K. Trench. 2000. Biogeography of two species of Symbiodinium (Freudenthal) inhabiting the intertidal sea anemone Anthopleura elegantissima (Brandt). Biol. Bull. 199: 126-134, doi:10.2307/1542872

Letsch, M. R., G. Muller-Parker, T. Friedl, and L. A. Lewis. 2009. Elliptochloris marina sp. nov. (Trebouxiophyceae, Chlorophyta), symbiotic green alga of the temperate Pacific sea anemones Anthopleura xanthogrammica and A. elegantissima (Anthozoa, Cnidaria). J. Phycol. 45: 1127-1135, doi:10.1111/j.1529-8817.2009.00727.x

LoRENZEN, C. J. 1966. A method for the continuous measurement of in vivo chlorophyll concentration. Deep-Sea Res. 13: $223-227$.

Lowry, O. H., N. J. Rosebrough, A. L. Farr, and R. J. RANDALL. 1951. Protein measurement with the Folin phenol reagent. J. Biol. Chem. 193: 265-275.

McBride, B. B., G. Muller-Parker, and H. H. Jakobsen. 2009. Low thermal limit of growth rate of Symbiodinium californium (Dinophyta) in culture may restrict the symbiont to southern populations of its host anemones (Anthopleura spp.; Anthozoa, Cnidaria). J. Phycol. 45: 855-863, doi:10.1111/j.1529-8817. 2009.00716.x

McCloskey, L. R., T. G. Cove, and E. A. Verde. 1996. Symbiont expulsion from the anemone Anthopleura elegantissima (Brandt) (Cnidaria; Anthozoa). J. Exp. Mar. Biol. Ecol. 195: 173-186, doi:10.1016/0022-0981(95)00079-8

Muller-Parker, G., and S. K. Davy. 2001. Temperate and tropical algal-sea anemone symbioses. Invertebr. Biol. 120: 104-123, doi:10.1111/j.1744-7410.2001.tb00115.x

- J. Pierce-Cravens, and B. L. Bingham. 2007. Broad thermal tolerance of the symbiotic dinoflagellate Symbiodinium muscatinei (Dinophyta) in the sea anemone Anthopleura elegantissima (Cnidaria) from northern latitudes. J. Phycol. 43: 25-31, doi:10.1111/j.1529-8817.2006.00302.x

Muscatine, L. 1971. Experiments on green algae coexistent with zooxanthellae in sea anemones. Pac. Sci. 25: 13-21.
Parsons, T. R., Y. Maita, And C. M. Lalli. 1984. A manual of chemical and biological methods for seawater analysis. Pergamon.

Rodolfo-Metalpa, R., S. Reynaud, D. Allemand, and C. Ferrier-PAgÈs. 2008. Temporal and depth responses of two temperate corals, Cladocora caespitosa and Oculina patagonica, from the north Mediterranean Sea. Mar. Ecol. Prog. Ser. 369: 103-114, doi:10.3354/meps07608

Saunders, B. K., and G. Muller-Parker. 1997. The effects of temperature and light on two algal populations in the temperate sea anemone Anthopleura elegantissima (Brandt, 1835). J. Exp. Mar. Biol. Ecol. 211: 213-224, doi:10.1016/ S0022-0981(96)02723-2

Secord, D., And L. Augustine. 2000. Biogeography and microhabitat variation in temperate algal-invertebrate symbioses: Zooxanthellae and zoochlorellae in two Pacific intertidal sea anemones, Anthopleura elegantissima and $A$. xanthogrammica. Invertebr. Biol. 119: 139-146, doi:10.1111/ j.1744-7410.2000.tb00002.x

—, AND G. Muller-PARKer. 2005. Symbiont distribution along a light gradient within an intertidal cave. Limnol Oceanogr. 50: 272-278, doi:10.4319/lo.2005.50.1.0272

Stockner, J. G., D. D. Cliff, and K. R. S. Shortreed. 1979. Phytoplankton ecology of the Strait of Georgia, British Columbia. J. Fish. Res. Board Can. 36: 657-666, doi:10.1139/ f79-095

Thom, R. M., and R. G. Albright. 1990. Dynamics of benthic vegetation standing-stock, irradiance, and water properties in central Puget Sound. Mar. Biol. 104: 129-141, doi:10.1007/ $\mathrm{BF} 01313166$

Thornhill, D. J., T. C. LaJeunesse, D. W. Kemp, W. K. Fitt, AND G. W. Schmidt. 2006. Multiyear, seasonal genotypic surveys of coral-algal symbioses reveal prevalent stability or postbleaching reversion. Mar. Biol. 148: 711-722, doi:10.1007/s00227-005-0114-2

van Oppen, M. J. H., A. C. Baker, M. A. Coffroth, and B. L. WiLLis. 2009. Bleaching resistance and the role of algal endosymbionts, p. 83-102. In M. J. H. van Oppen and J. M. Lough [eds.], Coral bleaching. Springer-Verlag.

Verde, E. A., AND L. R. McCloskey. 2007. A comparative analysis of the photobiology of zooxanthellae and zoochlorellae symbiotic with the temperate clonal anemone Anthopleura elegantissima (Brandt). III. Seasonal effects of natural light and temperature on photosynthesis and respiration. Mar. Biol. 152: 775-792, doi:10.1007/s00227-007-0737-6

Warner, M. E., G. C. Chilcoat, F. K. McFarland, and W. K. FitT. 2002. Seasonal fluctuations in the photosynthetic capacity of photosystem II in symbiotic dinoflagellates in the Caribbean reef-building coral Montastraea. Mar. Biol. 141: 31-38, doi:10.1007/s00227-002-0807-8

Associate editor: Christopher M. Finelli

Received: 21 March 2011

Accepted: 03 August 2011

Amended: 09 August 2011 